\title{
Marine Resource Management for Misali Island: Preliminary Analysis by Frontier-Tanzania
}

\author{
C. Daniels', 2, E. Fanning ${ }^{1}$ and D. Redding' \\ ${ }^{\prime}$ Society for Environmental Exploration, 50-52 Rivington Street, London, EC2A 3QP UK; \\ ${ }^{2}$ Frontier-Tanzania, P.O. Box 9473, Dar es Salaam, Tanzania
}

\begin{abstract}
Key words: Misali, Pemba, fisheries, resource management, non-extraction zone, artisanal fishing
Abstract - In collaboration with local stakeholders, Frontier-Tanzania is collecting biophysical information to facilitate effective management initiatives for Misali Island, where marine resource management is currently limited to a $1.4-\mathrm{km}^{2}$ non-extraction zone within a $21.6-\mathrm{km}^{2}$ conservation area. In the study reported here, the extraction and non-extraction zones at Misali Island with similar substrata were compared. Data analysis showed a significant disassociation in both abundance and mean length patterns of fish families found in each zone. Further analysis using t-tests on individual families showed that some groups were significantly more abundant in either zone, but without significant differences of mean lengths.

Fish family abundance and length records within and outside the non-extraction zone are likely to be affected to varying degrees by a combination of four main factors, including (i) direct fishing effects through target species, (ii) indirect fishing effects through catch of predatory species, (iii) habitat-dependence and (iv) effectiveness of the non-extraction zone.
\end{abstract}

\section{INTRODUCTION}

The Zanzibar archipelago, consisting of Pemba and Unguja Islands, is located to the east of the Tanzania mainland within the western Indian Ocean. Both Unguja and Pemba have a number of sites of regional and international importance for marine biodiversity (UNEP, 1989), and Pemba is world-renowned for its spectacular marine resources. However, the resources are increasingly threatened (Horrill et al., 1994), and there is a paucity of biophysical information on which to base future management initiatives for the Pemba region. Thus, further research is clearly needed.

Misali Island is located approximately $10 \mathrm{~km}$ to the west of Chake Chake, Pemba (northern part of land mass centered at $05^{\circ} 14^{\prime} 25^{\prime \prime}$ South, $039^{\circ}$ 36' 13" East) (Fig. 1). The importance of the island was highlighted by recent site visits, which revealed that surrounding marine areas suffered badly from the 1998 El Niño-related global coral bleaching event (Pers. observ.; Mohammed et al., 2000; Richmond \& Mohammed, 2001). Moreover, it has been considered likely that Misali Island interacts with other regional reefs and coastal habitats. These interactions include larval supply, resource use and anthropogenic impacts (Horrill, 1992). With its extensive seagrass and mangrove stands, and reefs, the island is important to the local fishing industry.

\section{Misali Island's current management status}

The Misali Island Marine Conservation Area (MIMCA) was legally established by the then Ministry of Agriculture, Livestock and Natural Resources, Zanzibar, through the Fisheries Act, No. 8 of 1988 and the Forest Resources Management and Conservation Act, No. 10 of 1996. At present, 


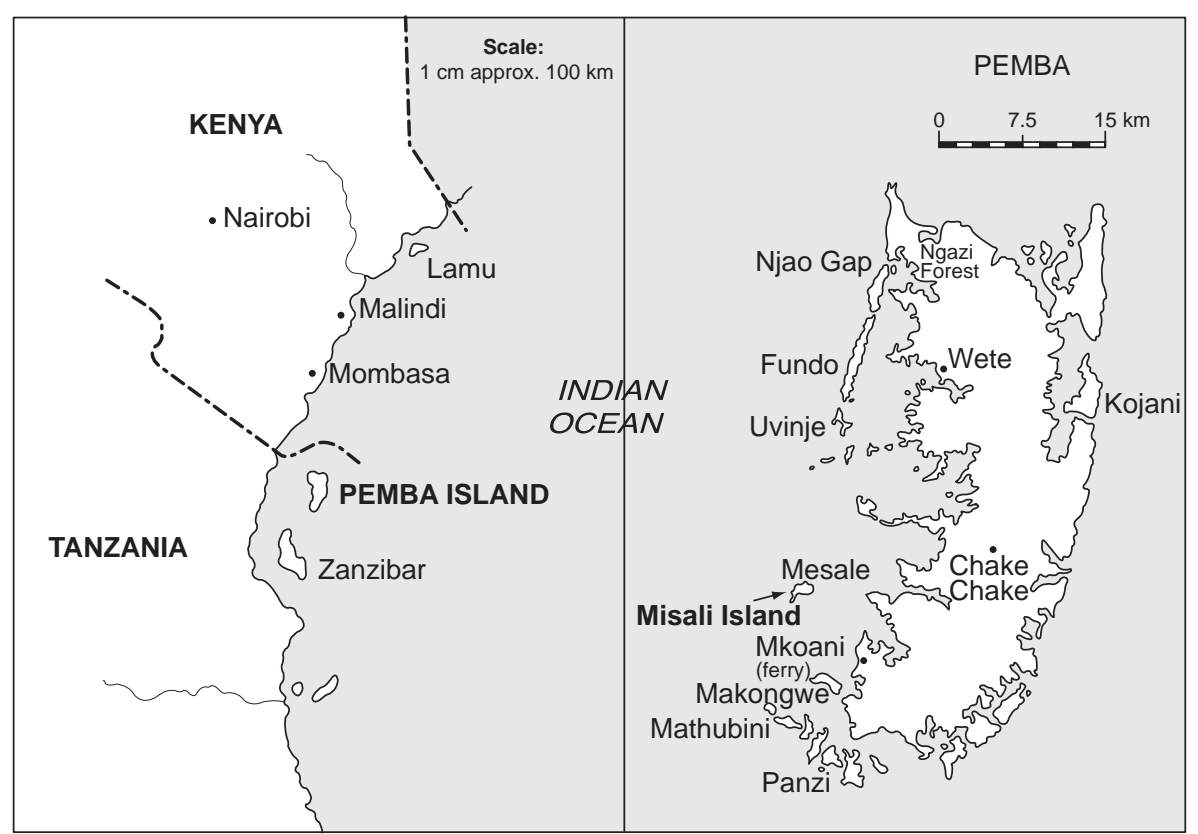

Fig. 1. Left: Coastline of Tanzania showing Pemba Island. Right: Pemba Island showing the location of Misali Island

the management of Misali Island is limited to a $1.4-\mathrm{km}^{2}$ non-extraction zone within a designated conservation area $\left(21.6 \mathrm{~km}^{2}\right.$ in total $)$, which was established May 1998. Recreational activities, passage and scientific research are permitted within the non-extraction zone, but any type of activity that depletes the area's natural resources is not. The Misali Island Conservation Association (MICA) manages these areas, including coordinating a team of rangers who reside on the island on a rotation basis. MICA is an NGO consisting primarily of fishermen, who represent the users from those shehiahs (areas) that most utilise Misali Island (Abdullah et al., 2000).

The study reported here was conducted as part of a programme undertaken in Pemba by FrontierTanzania-a collaboration between the University of Dar es Salaam (UDSM) and the Society for Environmental Exploration (SEE). The data analysed in this paper was selected for the purpose of assessing the effectiveness of the non-extraction zone around Misali Island.

Systematic surveys were undertaken to quantify the biophysical characteristics of Misali Island's ecosystems and to establish the natural and anthropogenic events that impact the locality.

\section{MATERIALS AND METHODS}

Figure 2 shows the 10 survey station locations around Misali Island selected by Frontier-Tanzania to be representative of all marine ecosystems observed in the local area (Pers. observ.; Horrill, 1992; Horrill et al., 1994; Richmond \& Mohammed, 2001).

The commercial fish visual census was conducted in a $5 \times 5 \times 5 \mathrm{~m}$ box, allowing it to be undertaken in low visibility. Fish abundance and estimated length, grouped by family, were recorded in 5-minute survey intervals for a total of 25 minutes. In addition, a census of reef-associated fish and benthic invertebrates was undertaken by direct observation with the aid of SCUBA, together with an appraisal of any natural or anthropogenic impacts. These surveys were undertaken at two different depth stations: the reef crest (4-8 m) and at a depth contour of 14-18 $\mathrm{m}$ on the face of the reef or substratum slope.

Snorkelling surveys in the region were also done and used in preparing a systematic fish inventory in the area. The benthos was mapped, also using SCUBA dives, to determine the percentage cover of substrate type using a categorical P6 scale (English et al., 1997), the 


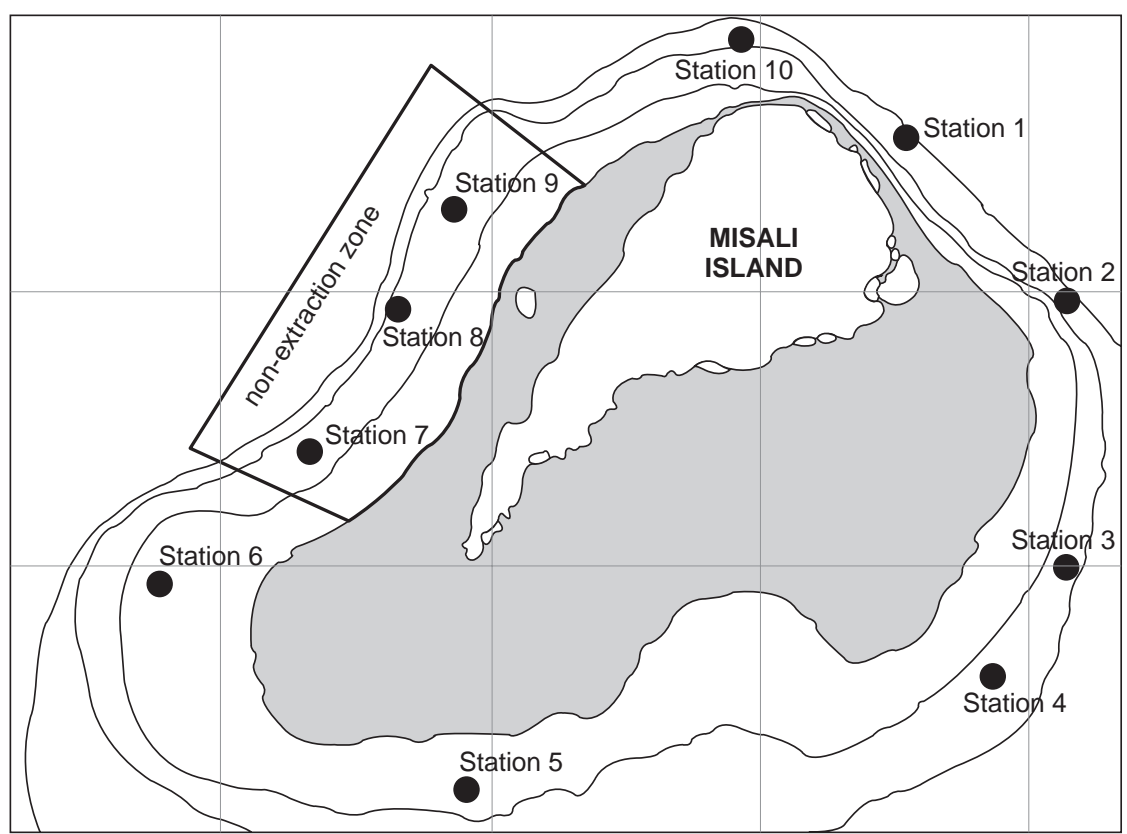

Fig. 2. Approximate survey station locations around Misali Island, and the position of the non-extraction zone (after Richmond \& Mohammed, 2001)

presence and dominance of coral morphotypes, and the substrate gradient. Quadrats measuring $2.5 \mathrm{x}$ $2.5 \mathrm{~m}$ were placed at 2-m intervals from $18 \mathrm{~m}$ depth to the reef crest.

All quantitative surveys were replicated at least eight times at each station and depth. A senior biologist made overview SCUBA dives as a check on survey reporting. Marine mammal sighting and a visual census of other marine resources around the island were made from a surface vessel.

A total of 32 datasets from surveys conducted as detailed above were analysed in this study. Half of these surveys were undertaken within the nonextraction zone and the other half outside it. Fish abundances and mean lengths were analysed initially using chi-squared tests, followed by further analysis with t-tests.

\section{RESULTS}

\section{Benthic substrate analysis}

The data summarised in Table 1 were used to identify comparable stations within and outside of the non-extraction zone. Accounting for substrate similarity and given the number of replications to date (due to weather and tidal restrictions), stations
7, 9 (non-extraction zone), 10 and 1 (extraction zone) were selected for comparison. It is noted that Station 1 has a narrow band of coral as opposed to a fairly extensive wall or slope.

\section{Fish abundance}

Figure 3 represents fish count data for 14 families from 16 replicate surveys within (stations 7 and 9) and 16 outside (stations 1 and 10) the nonextraction zone. The fish families are categorised into predominant dietary preference groups. Fish classified as 'invertivores', such as Lethrinidae (emperors) and Mullidae (goatfish), may include small fish in their diets but are unlikely to prey upon other families included in these surveys (Lieske \& Myers 1996). In contrast, the piscivore groups prey upon larger fish, and as such would conform to a higher trophic level. The data appear to show a superficial relationship, with invertivores predominating the extraction zone and herbivores the non-extraction zone. Subsequent analysis using a chi-squared test for association returned a highly significant disassociation $($ d.f $=13$; chi total $=531.39$; critical value, $\mathrm{CV}=22.36$ ) between the data collected from the two zones. 
Table 1. Summary of substrata composition at the stations surveyed around Misali island

\begin{tabular}{|c|c|c|c|c|c|c|c|}
\hline Station & Long. (S) & Lat. (E) & Depth (m) & Substratum composition & ASG $\%$ & $\mathrm{HCC} \%$ & $\mathrm{HCB} \%$ \\
\hline 1 & $05^{\circ} 14^{\prime} 11^{\prime \prime}$ & $039^{\circ} 36^{\prime} 37^{\prime \prime}$ & $\begin{array}{c}<16 \\
16-20\end{array}$ & $\begin{array}{l}\text { Narrow coral reef } \\
\text { Coral bommies }\end{array}$ & $\begin{array}{l}40^{\circ} \\
30^{\circ}\end{array}$ & $\begin{array}{l}11-30 \\
51-75\end{array}$ & $\begin{array}{l}1-10 \\
1-10\end{array}$ \\
\hline 2 & $05^{\circ} 14^{\prime} 25^{\prime \prime}$ & $039^{\circ} 36^{\prime} 53^{\prime \prime}$ & $\begin{array}{c}<6 \\
6-18\end{array}$ & $\begin{array}{l}\text { Seagrass and rubble with some coral } \\
\text { Mainly sand }\end{array}$ & $\begin{array}{l}30^{\circ} \\
30^{\circ}\end{array}$ & $\begin{array}{c}1-10 \\
0\end{array}$ & $\begin{array}{c}1-10 \\
0\end{array}$ \\
\hline 3 & $05^{\circ} 14^{\prime} 49^{\prime \prime}$ & $039^{\circ} 37^{\prime} 03^{\prime \prime}$ & $\begin{array}{c}<6 \\
6-25\end{array}$ & $\begin{array}{l}\text { Patches of soft coral and seagrass beds } \\
\text { Predominantly sand with intermittent } \\
\text { small- to medium-sized coral bommies }\end{array}$ & $5^{\circ}$ & $1-10$ & 0 \\
\hline 4 & $05^{\circ} 15^{\prime} 08^{\prime \prime}$ & $039^{\circ} 36^{\prime} 52^{\prime \prime}$ & & Similar to Station 3 & & & \\
\hline 5 & $05^{\circ} 15^{\prime} 30^{\prime \prime}$ & $039^{\circ} 35^{\prime} 55^{\prime \prime}$ & & $\begin{array}{l}\text { Not surveyed to date (October 2001) } \\
\text { due to weather restrictions }\end{array}$ & & & \\
\hline 6 & $05^{\circ} 14^{\prime} 45^{\prime \prime}$ & $039^{\circ} 35^{\prime} 27^{\prime \prime}$ & $\begin{array}{c}<18 \\
18-25\end{array}$ & $\begin{array}{l}\text { Predominantly bare rock with some } \\
\text { live coral cover } \\
\text { Sand lagoons and foliose coral beds } \\
\text { (Echinopora sp.) }\end{array}$ & $\begin{array}{l}30^{\circ} \\
10^{\circ}\end{array}$ & $\begin{array}{l}11-30 \\
51-75\end{array}$ & $\begin{array}{r}11-30 \\
11-30\end{array}$ \\
\hline 7 & $05^{\circ} 14^{\prime} 40^{\prime \prime}$ & $039^{\circ} 35^{\prime} 31^{\prime \prime}$ & & Similar to Station 6 & & & \\
\hline 8 & $05^{\circ} 14^{\prime} 26^{\prime \prime}$ & $039^{\circ} 35^{\prime} 40^{\prime \prime}$ & $\begin{array}{c}<8 \\
8-30\end{array}$ & $\begin{array}{l}\text { Coral wall } \\
\text { Coral wall }\end{array}$ & $\begin{array}{l}10-60^{\circ} \\
>60^{\circ}\end{array}$ & $\begin{array}{c}1-10 \\
11-30\end{array}$ & $\begin{array}{c}11-30 \\
1-10\end{array}$ \\
\hline 9 & $05^{\circ} 14^{\prime} 10^{\prime \prime}$ & $039^{\circ} 35^{\prime} 49^{\prime \prime}$ & $\begin{array}{c}<5 \\
5-18\end{array}$ & $\begin{array}{l}\text { Coral reef crest } \\
\text { Coral wall }\end{array}$ & $\begin{array}{l}<10^{\circ} \\
>40^{\circ}\end{array}$ & $\begin{array}{l}11-30 \\
31-50\end{array}$ & $\begin{array}{r}11-30 \\
1-10\end{array}$ \\
\hline 10 & $05^{\circ} 14^{\prime} 01^{\prime \prime}$ & $039^{\circ} 36^{\prime} 07^{\prime \prime}$ & $15-18$ & $\begin{array}{l}\text { Coral reef crest, descending to } \\
\text { coral reef slope, with sand gulley } \\
\text { at approximately } 15 \mathrm{~m} \\
\text { Sand gulley with intermittent coral } \\
\text { bommies deeper }\end{array}$ & $<10-30^{\circ}$ & $1-10$ & $1-10$ \\
\hline
\end{tabular}

ASG, Approximate substratum gradient; HCC, hard coral cover; HCB, hard coral bleached

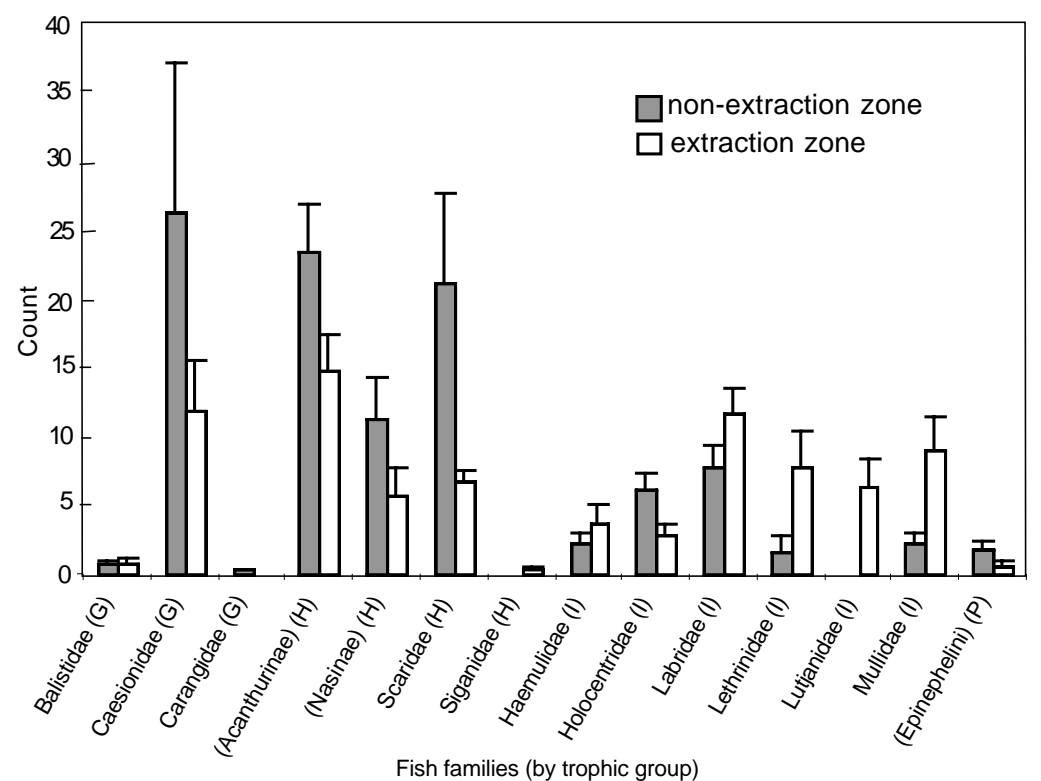

Fig. 3. Frequencies of fish families, comparing those surveyed within the non-extraction zone with those outside it, categorised by dietary preferences (or trophic group). G, generalist; H, herbivore; I, invertivore; P, Piscivore. 
Following the chi-squared analysis, two-tailed t-tests (chosen on the basis of a test for equal variance) were conducted on observed frequencies of each family within and outside the non-extraction zone (Table 2). The data were transformed using arcsinh to normalise distribution, which meant parametric assumptions were then satisfied. Statistical differences were found between some of the fish families (Table 2, highlighted in grey).

Although individuals of Cheilinus undulatus (humphead/Napolean wrasse), Sphyraenidae (barracuda), Carcharhinidae (requiem sharks),
Dasyatidae, Myliobatidae and Mobulidae (sting, eagle and manta rays respectively) or Muraenidae (moray eels) were sighted during surveys outside of the working quadrats, none were observed at the stations selected for data analysis. As such, data on these groups could not be analysed.

\section{Fish mean length}

There was a statistically significant disassociation (d.f. $=13$; Chi Total $=80.58 ; \mathrm{CV}=22.36$ ) between lengths of fish families and the zone in which they

Table 2. Summary of t-test for frequencies of fish observed within and outside non-extraction zone, grouped by family and dietary preference. Families highlighted in grey are significantly different by a two-tailed t-test

\begin{tabular}{|c|c|c|c|c|c|}
\hline Fish family (Dietary preference) $)^{1}$ & t-test used ${ }^{2}$ & t-statistic & $\begin{array}{l}\text { t-critical } \\
\text { (2-tailed) }\end{array}$ & P-value & Dominant zone \\
\hline Balistidae (G) & $\mathrm{E}$ & 0.25 & 2.04 & 0.81 & Extraction \\
\hline Caesionidae (G) & $\mathrm{E}$ & 0.27 & 2.04 & 0.79 & Non-extraction \\
\hline Carangidae (G) & $\mathrm{n} / \mathrm{a}$ & 1.81 & 2.13 & 0.09 & Non-extraction \\
\hline Labridae $(\mathrm{G})$ & $\mathrm{E}$ & 1.51 & 2.04 & 0.14 & Extraction \\
\hline Acanthuridae (Acanthurinae) $(\mathrm{H})$ & $\mathrm{E}$ & 1.83 & 2.04 & 0.08 & Non-extraction \\
\hline Acanthuridae (Nasinae) $(\mathrm{H})$ & $\mathrm{E}$ & 1.48 & 2.04 & 0.15 & Non-extraction \\
\hline Scaridae $(\mathrm{H})$ & $\mathrm{E}$ & 2.98 & 2.04 & 0.08 & Non-extraction \\
\hline Siganidae $(\mathrm{H})$ & $\mathrm{n} / \mathrm{a}$ & $\mathrm{n} / \mathrm{a}$ & $\mathrm{n} / \mathrm{a}$ & $\mathrm{n} / \mathrm{a}$ & Non-extraction \\
\hline Haemulidae (I) & $\mathrm{E}$ & 0.76 & 2.04 & 0.45 & Extraction \\
\hline Holocentridae (I) & $\mathrm{E}$ & 2.16 & 2.04 & 0.04 & Non-extraction \\
\hline Lethrinidae (I) & $\mathrm{N}$ & 2.54 & 2.06 & 0.02 & Extraction \\
\hline Lutjanidae (I) & $\mathrm{n} / \mathrm{a}$ & 3.97 & 2.13 & 0.00 & Extraction \\
\hline Mullidae (I) & $\mathrm{E}$ & 3.88 & 2.04 & 0.00 & Extraction \\
\hline Serranidae (Epinephelini) (P) & $\mathrm{E}$ & 1.20 & 2.04 & 0.24 & Non-extraction \\
\hline
\end{tabular}

${ }^{1} \mathrm{G}$, generalist; H, herbivore; I, invertivore; P, piscivore. ${ }^{2}$ Equal (E)/non-equal $(\mathrm{N})$ variance.

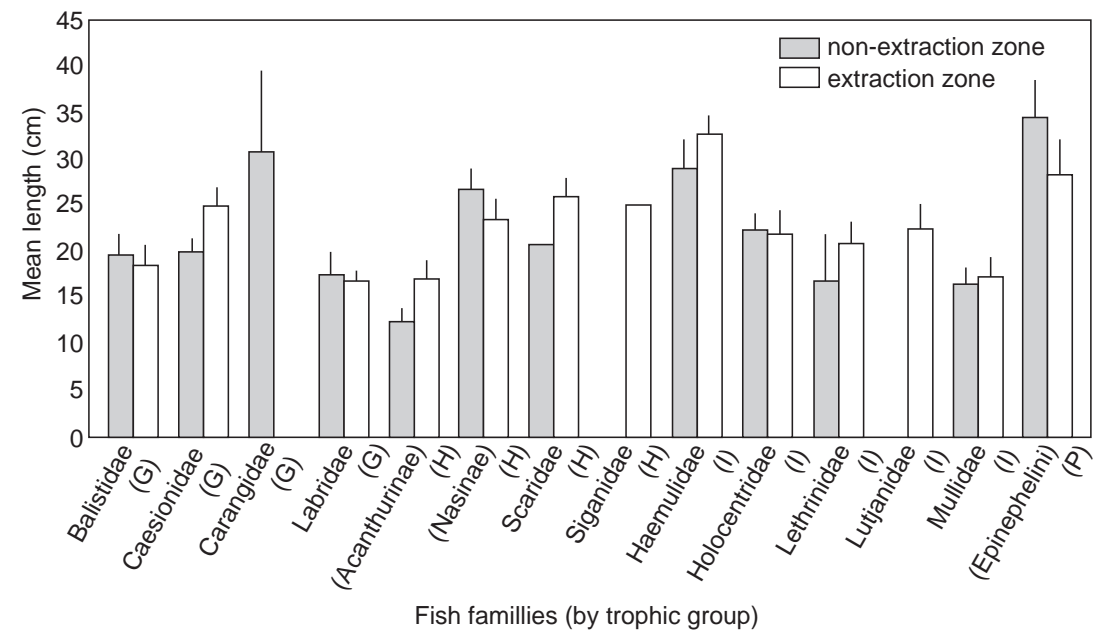

Fig. 4. Mean lengths for fish families, comparing those surveyed within the non-extraction zone with those outside it. G, generalist; H, herbivore; I, invertivore; P, piscivore. 
Table 3. Summary of t-test for mean length of fish observed within and outside non-extraction zone, grouped by family and dietary preference

\begin{tabular}{|c|c|c|c|c|c|}
\hline Fish family (Dietary preference) ${ }^{1}$ & t-test used ${ }^{2}$ & t-statistic & $\begin{array}{l}\text { t-critical } \\
\text { (2-tailed) }\end{array}$ & P-value & Dominant zone \\
\hline Balistidae $(\mathrm{G})$ & $\mathrm{E}$ & 0.13 & 2.20 & 0.90 & Extraction \\
\hline Caesionidae (G) & $\mathrm{N}$ & 0.66 & 2.13 & 0.52 & Extraction \\
\hline Carangidae (G) & $\mathrm{n} / \mathrm{a}$ & $\mathrm{n} / \mathrm{a}$ & $\mathrm{n} / \mathrm{a}$ & $\mathrm{n} / \mathrm{a}$ & $\mathrm{n} / \mathrm{a}$ \\
\hline Labridae $(\mathrm{G})$ & $\mathrm{E}$ & 1.17 & 2.05 & 0.25 & Non-extraction \\
\hline Acanthuridae (Acanthurinae) $(\mathrm{H})$ & $\mathrm{E}$ & 0.49 & 2.05 & 0.63 & Extraction \\
\hline Acanthuridae (Nasinae) $(\mathrm{H})$ & $\mathrm{E}$ & 0.52 & 2.06 & 0.61 & Non-extraction \\
\hline Scaridae $(\mathrm{H})$ & $\mathrm{E}$ & 0.46 & 2.04 & 0.65 & Extraction \\
\hline Siganidae $(\mathrm{H})$ & $\mathrm{n} / \mathrm{a}$ & $\mathrm{n} / \mathrm{a}$ & $\mathrm{n} / \mathrm{a}$ & $\mathrm{n} / \mathrm{a}$ & $\mathrm{n} / \mathrm{a}$ \\
\hline Haemulidae (I) & $\mathrm{E}$ & 1.45 & 2.16 & 0.17 & Extraction \\
\hline Holocentridae (I) & $\mathrm{E}$ & 0.38 & 2.07 & 0.71 & Non-extraction \\
\hline Lethrinidae (I) & $\mathrm{N}$ & 0.51 & 2.57 & 0.63 & Extraction \\
\hline Lutjanidae (I) & $\mathrm{n} / \mathrm{a}$ & $\mathrm{n} / \mathrm{a}$ & $\mathrm{n} / \mathrm{a}$ & $\mathrm{n} / \mathrm{a}$ & $\mathrm{n} / \mathrm{a}$ \\
\hline Mullidae (I) & E & 0.72 & 2.06 & 0.48 & Non-extraction \\
\hline Serranidae (Epinephelini) (P) & $\mathrm{E}$ & 0.62 & 2.14 & 0.54 & Extraction \\
\hline
\end{tabular}

${ }^{1} \mathrm{G}$, generalist; H, herbivore; I, invertivore; P, piscivore. ${ }^{2}$ Equal $(\mathrm{E}) /$ non-equal $(\mathrm{N})$ variance.

were observed. However, from Fig. 4, there appears to be little obvious pattern between the dietary groups and the zones in which they were found. Ttests performed on mean length data revealed no significant differences between fish families in the two zones compared (Table 3).

\section{DISCUSSION}

\section{Benthic substrata analysis}

The results on benthic substrata presented in this paper (Table 1) give a preliminary description of stations surveyed around Misali Island and allow comparable stations to be chosen for discrete analysis. In fact, station 6 (in the extraction zone) is more comparable to the non-extraction zone than station 1, and would have been a more appropriate selection. However, due to a limited number of replications at the time of analysis the next closest comparable station was selected.

\section{Fish abundance}

\section{Direct effects of fishing practice following removal of specific target species}

In order to assess the impact of fishing practice upon fish species inside and outside of the nonextraction zone, fisheries data is necessary. We have observed that some fishing is conducted within the non-extraction zone, though far less than outside it. Fishing (apart from that in intertidal areas) is predominantly done from outrigger canoes (ngalawa) using hand-lines (mshipi) at night in the deeper waters around Misali Island. The majority of the fish caught consist of Carangidae (jacks and trevallys), Labridae (wrasses), Lethrinidae, Lutjanidae (snappers) and Sphyraenidae (Richmond \& Mohammed, 2001; data recorded by MICA rangers; Pers. observ.). All these families, except Carangidae, were observed in greater abundance in the extraction zone, which indicates that abundance differences could not be attributed solely to fishing levels.

Increasing fishing pressure, overfishing and reduced artisanal fish landings have been recorded within Tanzania, mainly as a result of a rising coastal population (UNEP, 1989; 2001). Shark fin trade and the shark and ray catches have declined and "some fish species are now rarely seen in Tanzanian waters" (UNEP, 2001). Removal of target groups such as Carcharhinidae, Dasyatidae, Myliobatidae, Mobulidae and large Epinephelini (Serranidae [groupers]) may explain why these were not observed during surveys (similar absences were reported by Richmond \& Mohammed, 2001) and why less Epinephelini were observed in the extraction zone compared to the non-extraction zone. However, not all fish family groups known 
to be the targets of fishing are shown to be affected in this way and overall, there is little significant difference between abundance of fish families found within and outside the non-extraction zone. Such observations, however, are similar to those recorded by Jennings and Polunin (1997), who found that only the piscivorous species appeared to show a decline in numbers as a result of increased fishing levels. It is likely that many habitat-dependent (food availability, territorial behaviour) and oceanographic (e.g. current patterns, [Chabanet et al., 1997]) factors influence the remaining dietary groups in different ways. This results in contradictory or insignificant findings when comparing two areas with different levels of fishing pressure.

\section{Indirect effects of fishing practice}

Figure 3 shows that invertivore fish families were superficially observed with greater abundance in the extraction zone, whereas herbivorous fish were more frequently observed in the non-extraction zone. Variations were confirmed by t-tests, where most significant differences are found amongst the invertivores. It is possible that the relatively higher abundance of invertivores in the extraction zone is due to there being fewer of their predators. Such a reduction of predator species may be a result of increased concentration of fishing practice in the extraction zone since the implementation of the no-fishing rule in the non-extraction zone. Jennings and Polunin (1997) reiterate that the dominance of smaller, faster growing, low trophic level fish species is indicative of intensively fished areas, implying perhaps that the difference in levels of invertivore-feeding fish in this study is due to a lack of predators in the extraction zone. The higher numbers of piscivorous Serranidae found in the non-extraction zone, while not significant in this study could, with increased replication, lend support to this hypothesis.

\section{Fish dependence on substrata}

Other factors such as benthic substrata types could affect the abundance of fish found in different areas (Hixon, 1991; Chabanet et al., 1997). With this in mind, the stations compared in this paper were selected to reduce such a factor as much as possible. However, coral reef cover decreases dramatically outside the non-extraction zone, hence natural provision of physical habitats and shelter sites are also reduced (Daniels et al., in press). Such habitats potentially provide structure and food for reef-specific fish such as acanthuroids (surgeons and unicorns) as well as indirect provision for open-water piscivorous predators such as carangids and sphyraenids. These piscivorous families prey upon planktivores such as caesionids (fusiliers), which take advantage of the hydrological features generated by reefs that retain and concentrate plankton (Choat \& Belwood, 1991).

Given such reef-dependencies and interactions by non-reef species, a greater array of fish would be expected on reefs, compared to non-reef or sandy areas, as shown by Chabanet et al. (1997) and Daniels et al. (in press). This explanation correlates with the data presented in this paper, given that predominantly reef-specific fish such as acanthuroids and scarids (parrotfish) were observed in greater abundance in the nonextraction zone, which has greater reef coverage than the extraction zone. In contrast, other families that are less reliant on coral reefs (such as Caesionidae, Carangidae, Haemulidae (sweetlips), Lethrinidae, Lutjanidae, Mullidae, Serranidae and Sphyraenidae) were observed in varying abundance within and outside the non-extraction zone.

\section{Additional factors}

A statistical difference was observed in the patterns of fish family abundance distributed inside and outside the non-extraction zone. However, given that few families showed significant differences when analysed with t-tests, the differences generated by chi-squared analyses are likely to be due to zero values recorded for some of the families (see discussion below).

\section{Fish length}

There was a significant disassociation between the mean lengths of fish families surveyed inside and outside the non-extraction zone. However, no significant differences were present in individual families within either area (t-test). From the plot of average lengths (Fig. 4), it can be seen that there 
is little obvious direction between fish groups observed in either zone, and no obvious pattern between dietary preferences.

It is likely that the disassociation test was influenced by the absence of some fish families during survey observations. If the zero count families exist in both areas this result must be explained through methodological difficulties. Surveys were separated into 5-minute intervals to allow assessment of abundance in terms of individuals or schools. Such ecological behaviour affects data by showing larger differences between zero observations and those of a few schools of fish. For example, there is a large difference in the number of Caesionidae, a schooling fish family (Lieske \& Myers 1996), when comparing observations inside (421 individuals) and outside (196 individuals) the non-extraction zone. However, the number of groups or shoals sighted during surveys are almost equal (21 inside the nonextraction zone, 22 outside this area). It is likely that this plays a major factor in the data analysis. With shoaling fish the individual fish counts are in effect pseudo-replications and as such the data have been interpreted on the basis of just one or two actual sightings. It is probably more accurate to analyse the abundance of shoals rather than individuals, but this would require extensive further replication. However, as previously stated, the data here represent only a small selection of that collected by Frontier-Tanzania, so this procedure will be possible in the future.

The similarity of average lengths between families and zones could generate a number of conclusions. Many studies suggest that a common impact of fishing pressure is a reduction in the average adult length of target fish species (such as Jennings \& Polunin, 1997; Jennings et al., 1995). The fact that this has not been reflected in our study could be due to several reasons: It is possible that the non-extraction zone is ineffective due to its limited size $\left(1.4 \mathrm{~km}^{2}\right)$, hence fish with large ecological ranges such as Carangidae are likely to rove further afield, and not benefit from such a refuge size. As such, either fishing pressure is not great enough to affect species size at maturity or such changes are undetectable due to fish being equally affected both inside and outside the nonextraction zone.
The fact that the non-extraction zone and Misali Island conservation area as a whole have only been established for the relatively short period of time of approximately 3 years, and that some fishermen continue to fish in the restricted area may prevent observable effects to date. When considering consequences of fishing practice, such as effects on fish abundance and sizes between the zones, spillover effects must be taken into account, as fishing continues to be practised within the nonextraction zone. This will be possible with increasing replication and detailed analysis of stations surveyed at varying distances from the non-extraction zone.

Further research is needed, including:

- comparisons within and outside the nonextraction zone and conservation area; and

- long-term assessment of fisheries practices.

Acknowledgements-This project is conducted in association with the Ministry of Agriculture, Natural Resources, Environment and Cooperatives (MANREC) of the Zanzibar Revolutionary Government, and the authors are grateful to Dr B. Asseid and Mr Ali Said for their continued co-operation. Thanks are due to Dr N. S. Jiddawi of the Institute of Marine Sciences (IMS) and Professor Howell and Dr Muruke of University of Dar es Salaam for their commitment and support. This project is funded by Society for Environmental Exploration (SEE) with donations of solar panels and fuel from BP-Tanzania. Dr Damon Stanwell-Smith provided comments on a draft of this manuscript.

\section{REFERENCES}

Abdullah, A., Hamad, A.S., Mbarouk, A. \& Wild, R.G. (2000) Constituting the commons: crafting sustainable commons in the new millennium. 8th Biennial Conference of the International Association for the Study of Common Property (IASCP), Pemba, 11 pp.

Chabanet, P., Ralambondrainy, H., Amanieu, M., Faure, G. \& Galzin, R. (1997) Relationships between coral reef substrata and fish. Coral Reefs 16: $93-102$.

Choat, J.H. \& Belwood, D.R. (1991) Reef fishes: Their history and evolution. In: Sale, P.F. (ed.) The ecology of reef fishes on coral reefs. pp. 39-66. 
Daniels, C., Fanning, E. \& Jiddawi, N. (eds) Misali Island: A detailed description of the subtidal regions. Frontier-Tanzania Environmental Research. Society for Environmental Exploration, UK, with the University of Dar es Salaam including the Institute of Marine Sciences and the Ministry of Agriculture Natural Resources and Environment Co-operatives, Zanzibar. 112 pp.

English, S., Wilkinson, C. \& Baker, V. (Eds) (1997) Survey manual for tropical marine resources, $2 \mathrm{nd}$ edition. Australian Institute of Marine Science, Townsville, Australia. $261 \mathrm{pp}$.

Hixon, M.A. (1991) Predation as a process structuring coral reef fish communities. In: Sale, P.F. (ed.) The ecology of reef fishes on coral reefs. pp. 475-508.

Horrill, J.C. (1992) The status of coral reefs of Misali Island, Pemba. The Commission for Lands and Environment, Zanzibar. Zanzibar Environmental Study Series. no. 13.12 pp.

Horrill, J.C., Machano, H. \& Omar, S.H. (1994) Misali Island: rationale for a marine protected area. The Commission for Lands and Environment, Zanzibar. Zanzibar Environmental Study Series. no. 17.9 pp.

Jennings, S., Grandcourt, E.M. \& Polunin, N.V.C. (1995) The effects of fishing on the diversity, biomass and trophic structure of Seychelles' reef fish communities. Coral Reefs 14: 225-235.
Jennings, S. \& Polunin, N.V.C (1997) Impacts of predator depletion by fishing on the biomass and diversity of non-target reef fish communities. Coral Reefs 16: 71-82.

Lieske, E. \& Myers, R. (1996) Coral reef fishes: Caribbean, Indian Ocean and Pacific Ocean, including the Red Sea. Harper Collins Publishers, Italy. $400 \mathrm{pp}$.

Mohammed, S.M., Muhando, C. \& Machano, H. (2000) Assessment of coral reef degradation in Tanzania: results of coral reef monitoring - 1999. Institute of Marine Science Report. 20 pp.

Richmond, M.D. \& Mohammed, S.M. (2001) A review of the fisheries of the Misali Island Marine Conservation Area (MIMCA), Pemba, with recommendations for monitoring. CARE Tanzania, Commission for Natural Resources, Zanzibar, Tanzania. $67 \mathrm{pp}$.

UNEP (1989) Coastal and marine environmental problems of the United Republic of Tanzania. UNEP Regional Seas Reports and Studies. no. 106. $114 \mathrm{pp}$.

UNEP (2001) Eastern Africa atlas of coastal resources-Tanzania. A project of the United Nations Environment Programme with the support of the Government of Belgium. United Nations Environment Programme. 111 pp. 